\author{
食のグローバル化と食生活の危機 \\ 一日本の農業・農政の課題一 \\ 柴田明夫 \\ (資源·食糧問題研究所代表)
}

\title{
Globalization of food and the crisis of the Japanese dietary habits
}

\author{
Akio Shibata \\ Natural Resource Research Institute, \\ 3-13, Nishiki-cho, Nasushiobara-shi, Tochigi, 325-0058 \\ ○325-0058 栃木県那須塩原市錦町 3-13
}

\begin{abstract}
Until now, Japan has been able to procure any amount of high quality food at low prices from overseas. However, as the international food market become more volatile in the 2000s, the three stability of "price", "quality" and "supply" that Japan has enjoyed so fa can no longer be guaranteed. Consumers are increasingly looking to domestic agriculture. But can Japanese agriculture meet these consumer expectations? Should Japanese Agriculture Policy Should Support Small-Scale Farmers Compatible with Nature in intermediate Regions in the Future? In area where conditions are unfavorable, the scale of management is unnecessarily expanded, aiming to improve management productivity by combing management and livestock production centered on rice cultivation. In other words, promoting agricultural reform based on tradition.
\end{abstract}

\section{1.はじめに}

日本の食料 ${ }^{1}$. 農業問題はわかり難い。過利と不足問 題が併存しているためである。日本は, 人口・GDP大 国であるにもかかわらず米, 小麦生産が約900万トンで 済んでいるのは, 約 3,000 万トンの穀物を輸入している ことによる。国内生産については長年過剩（Farm Problem）と問題視される一方, 輸入食糧については当 たり前と思われている。しかし，世界の食糧市場が不安 定化していることを考えると, 早晚, 輸入食糧について 「不足」(Food Problem) との認識が強まるだろう。

\section{2.「食」という財の 5 つの特徵}

「食」という財には, (1)絶対的な必需品（不足すれば 飢餓問題に発展), (2)食品の飽和性（消費能力に限界）, (3)安全性, (4)生鮮性, (5)習慣性（幼少時代の味は忘れら れない）という5つの特徵がある。食品の飽和性という 点では, 民俗学者の宮本常一は, 『食生活雑考』(未来社)
の中で, われわれの食生活の変遷には, 「変わる部分と 変わらぬ部分の 2 つがある」と指摘。江戸時代，秋田県 男鹿半島の寒風山麓で百姓をしていた人物や喜界島の住 民の日誌から, 彼らの食生活が一日2, 200〜2, 700キロカ ロリーのところに止まっていたことに気づく。「その変 わらないものは, 何がそれを変えないで今日までずっと 伝えさせて来たか。そういう力はどういうものか」と考 え，「風土が非常に大きな力をもっていた」とみる。

国際商品として食糧（穀物）をみる上では，(1)と(2)が 重要である。世界の食糧市場の安定のためには,「絶対 的な必需品」と「飽和性」としての食糧の間で, 需給が バランスすることが重要だ。しかし, 市場メカニズムの 下ではそのバランスは容易ではない。不足するとみれば 投機マネーによって価格は高騰し, 供給過剩とみれば価 格は急落する。逆に, 食糧はわずかな需給バランスの変 化でも価格が乱高下する。それ故, 食糧は国際市況商品 (commodity) と称され, 投機マネーの対象となるので ある。

食料は食物一般, 食糧は基礎食料である穀物。 
$1960=100$

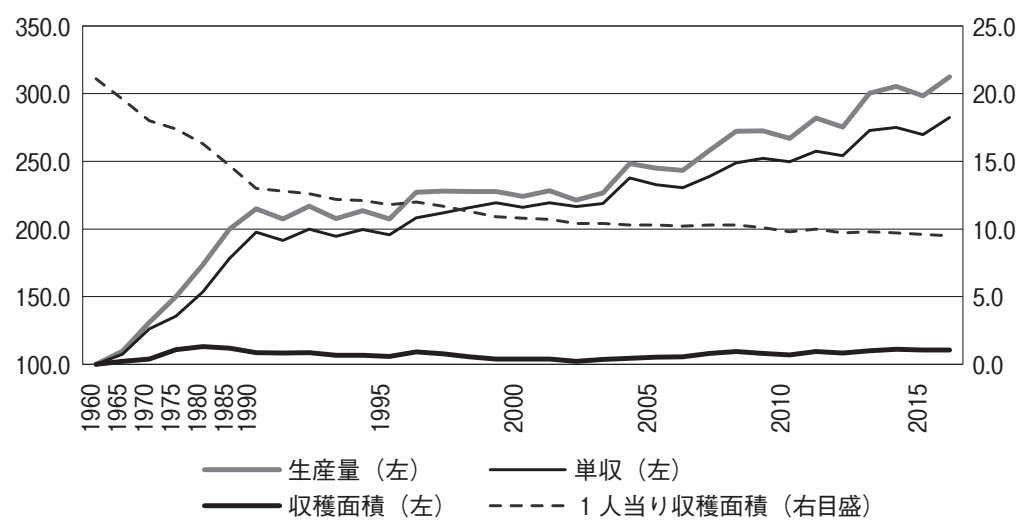

図 1 世界穀物生産量, 単収, 収穫面積, 1 人当たり収穫面積（ $\mathrm{a} /$ 人） 出所）FAO より筆者作成

\section{3. 日本の食品消費構造を変化させる 5 つの要因}

一般的に，食料消費構造は，(1)コーホート（cohort） 効果（出生率による世代特有の傾向。同時期に同様に体 験をして成長するため, 物に対する価值観など共通の意 識や行動を示すことが多い（例えば，出生年1960年を境 に外食利用率が急増するなど），(2)加齢効果（加齢によ る肉消費の減少など）, (3)時代効果（世代，年齢に関わ りないその時々の社会全体の傾向), (4)消費支出要因 (所 得の増減による影響), (5)価格要因 (それぞれの品目の 価格動向)，の5つの要因によって決まってくると考え られている。特に, 環太平洋パートナーシップ協定 (TPP) 合意など貿易自由化の影響は，主に価格要因を通じて現 れるとみられる。

\section{4. 地球はどれだけの人口を養うことができるか}

国連食糧農業機関（FAO）は，2050年までに世界で必 要な食糧生産量は，2000年（18億トン台）の 2 倍（36億 トン）とみている。地球温暖化により気象が「極端化」 し，作物の生育環境が大きく変化する中，われわれは， 農業の近代化により, さらに10億トンの食糧増産を限ら れた土地と水の制約の下で，実現していくことができる のだろうか。

一般に食糧生産の増加は, 耕地面積の拡大と単位面積 当たり収量の向上に依る。これはいわば耕地面積という ストックから毎年生み出されるフロー, すなわちダムか ら流れ出る流水量のようなものである。国連統計によれ ば，1960年の世界穀物生産量，収穫面積 ${ }^{2}$, 単収を基準 $（ 1960=100 ） に ， 2016$ 年まで56年間の推移をみると，穀 物生産量は3.12倍になっている（図 1)。収穫面積は 1981年までは1. 15倍に増えたものの，その後は頭打ちに ある。世界人口が1960年の約30億人から 2016 年に74億人 強へ2.5倍になったことから，1960年に21アールあった
1 人当たり収穫面積は, その後, 減少傾向を辿り, 足も とでは10アールを下回っている。

これに対し，単位面積当たり収量は2.82倍に上昇。世 界の食糧生産はもっぱら単収の増加によるものであるこ とがわかる。これを可能にしたのは主に農薬，肥料の大 量投入であり灌溉整備の拡大である。FAOによれば, 世界平均の耕地面積 1 ヘクタール当たり化学肥料（窒素, リン酸，カリウム）使用量は，1960年の 22 キログラムか ら 2012年には 125 キログラムと, この50年余りで 5 倍以 上に増加した。これが高収量品種 (HYV: High Yield Variety）の開発・普及とあいまって収量のアップをもた らした。

\section{5．農業近代化の光と影}

一般に, 農業の近代化とは, 自然依存型の伝統的な生 産システムを資本依存型の生産システムに転換すること である。具体的には，固場の（灌溉）整備，農薬・肥料・ 高収量品種 (HYV) の大量投入，農業機械の導入など により進められる。1960年代にアジアで普及した「緑の 革命」は農業近代化の例として知られている。「緑の革命」 により，フィリピン，インドネシア，インドなどの米の 収量は飛躍的に拡大し, 食糧自給化を果たした。しかし, こうした光の部分に対して，影の部分も指摘されている。 一つは，農業近代化は，農業的世界の慣習を崩す過程で, 農家の格差を拡大させたこと。もう一つは自然環境への 影響である。農業近代化は，特定の改良品種を導入する ことで，その地域で栽培されていた多様な品種が失われ， 結果として農業的世界の生態系を崩すことになる。

アメリカの社会生物学者エドワード・ウィルソンによ れば,「人類の歴史を通じて総計 7,000 種の植物が作物と して栽培され，食用として収穫されてきた」。しかし，「今 日世界食料の $90 \%$ を提供しているのはわずか 20 種類の植 物であり, しかもその内, 小麦, トウモロコシ, 米の 3

2 耕地面積の利用率によって収穫面積は変わるが，おおむね両者は同じとみた。

$146(6)$ 


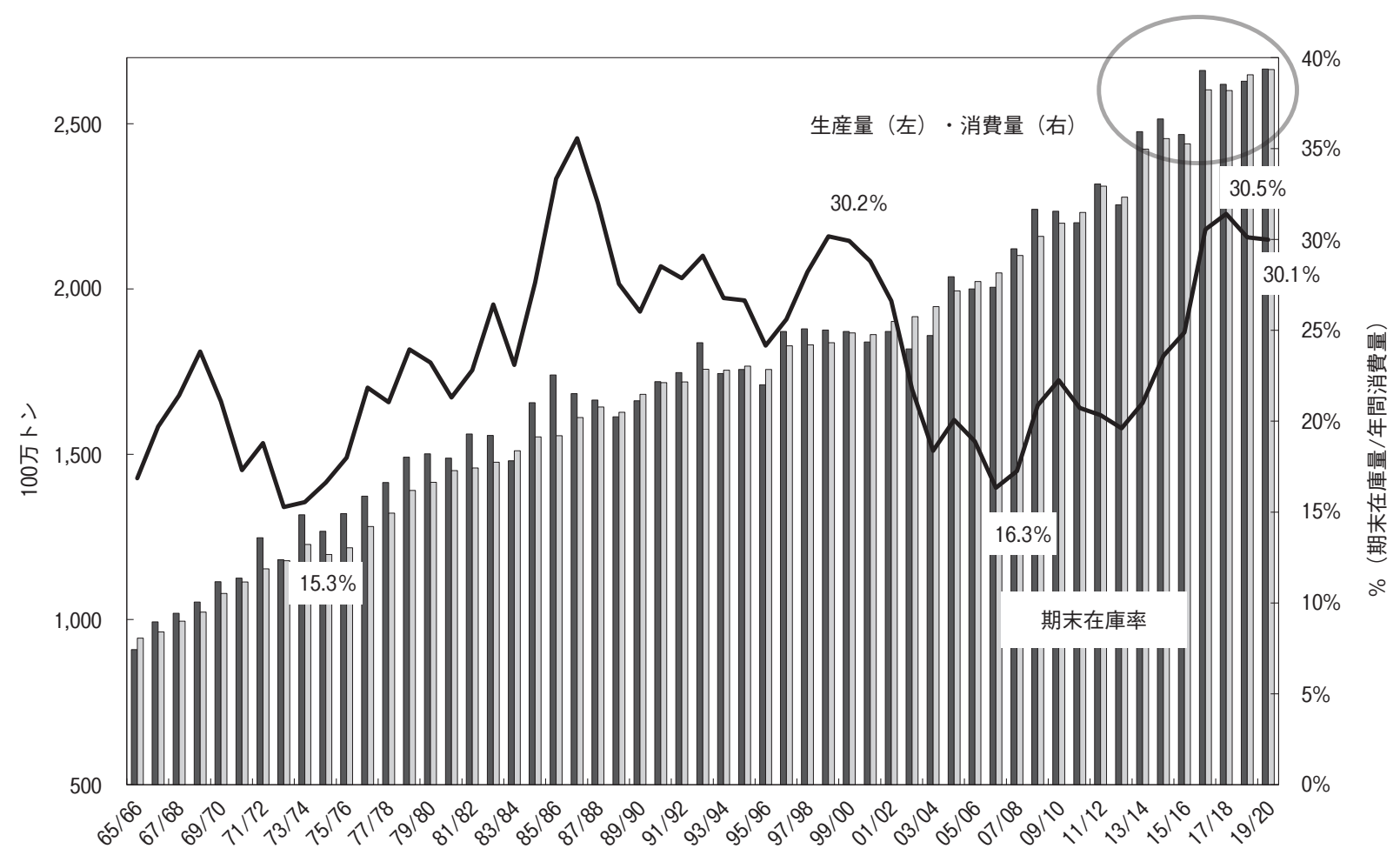

図 2 世界の穀物生産・消費と期末在庫率の推移

出所）アメリカ合臬国農務省：農産物需給報告（2019）上り筆者作成

種で全体の半分以上を占めている」と指摘している。こ の 3 大作物は，われわれ祖先の手が入ることで，その高 い単収, 栽培の容易さ, 味覚, 消化の容易さ, 貯蔵性, 加工性などの面で優位性を強め, 作物間競争を勝ち抜い てきたものである。問題は, この結果，世界の作物栽培 がほとんどの場所で単一栽培（モノカルチャー）になっ ていることである。ちなみに，世界の穀物（米, 小麦, トウモロコシ, 燕麦, ソバ, ライ麦, キビ, ヒエ, アワ など）の生産量は，1990年の19億トン台から2016年には 28億卜ン台に拡大した。しかし，この内の約 9 割が 3 大 款物（小麦, 米, トゥモロコシ）の生産である。特に, 今世紀に入ってからはトウモロコシの増産が著しい。

なぜ単一栽培が問題なのか。単一栽培であればそれだ け管理が容易だからだ。しかし，作物の多様性の維持と いう面では，環境変化に対しては極めて脆弱な構造にあ るといえよう。一般に, 農業と植物相（植物の種類）と の関係では，単純（単一栽培）なほど効率は良くなるが, 環境変化に対して不安定であり, 複雑 (多様な植物) な ほど効率は悪いが，環境変化に対して安定するといわれ る。したがって, 単純な植相 (単一栽培) を作りつつ, 同時に安定性を求めなければならないのが農業なのだ。

\section{6.一段と不安定化する世界の食糧市場}

ここ数年，世界の穀物市場はなにもかもが記録ずくめ となっている。アメリカ合衆国農務省（USDA）が2019 年12月10日に発表した $2019 / 20$ 年度（19年後半～20年前 半）の需給報告によれば, 世界の穀物生産量は，26億
6, 550万トンで, 史上 2 番目の豊作となる（図 2 )。この 結果, 足元の在庫量は 7 億 9,877 万トンと 8 億トンに迫り, 同在庫率（年間消費量に対する在庫量の比率）は $30 \%$ を 超え，FAO が適正とする $17 \%$ 前後（年間消費量の 2 力 月分）を大きく上回っている。シカゴ款物市場では， 7 年連続の豊作が続いたことで，2007年～2014年にかけて 高騰していた穀物価格も，2015年以降は落ち着いている。

これら数字をみる限り, 食糧問題（食糧は穀物, 食料 は食物一般）はすでに解決されたかのように見える。し かし, 安心はできない。世界の食糧市場が一段と不安定 化していることを見落としてはならない。

一つは，世界の穀物消費量も26億トンを上回り過去最 高水準にあることだ。世界の穀物消費量は1990年代後半 には18億トン台で推移していた。しかし，今世紀に入る と, 消費量は人口増加率を上回るペースで増加し, 毎年 のように過去最高を更新し続けている。中国，インドな どの新興工業国で, 経済成長に伴う所得の向上により食 料消費が増えているためだ。

所得が増えると「1人当たり食料消費量」が増え, 直 接穀物を消費する段階から乳や肉, 卵を消費する段階へ と移ってゆく。1 キログラムの豚肉を生産するには 7 キ ログラム, 牛肉では 11 キログラムの飼料が必要（ただ, 現在は飼料効率が良くなり数字は低下）であり，飼料用 需要を飛躍的に拡大させる「需要ショック」ともいえる 現象が生じている。実際，世界の穀物消費量の約半分は 家畜のエサなのである。特に, 中国では, 家畜にとって のたんぱく源となる大豆ミール（粕）の需要が急増し， 
飼料用の穀物需要は, 今後もアジアや中南米などを中心 に増えていくだろう。

もう一つは，穀物生産量が増えた理由も懸念材料た。 急増する穀物消費量に対して，これまでのところ生産量 も追いついている。しかし, それは増減産を繰り返しな がらの拡大であり，干ばつや洪水など異常気象の影響を 受けやすくなっている。農業は自然の中で営まれる産業 であり，大気や水系や土壤といった環境との関わりが深 い。人間の営みである農業が環境に負荷を与える一方, 逆に環境の変化が農業に大きな影響をもたらす。

こうした農業と環境の双方向の関係の中で，気になる のは，今世紀に入って世界的な農業開発ブームが起こり 開発のフロンティアが急速に拡大していることだ。特に, 2007年から2013年にかけて穀物価格が高騰したことを受 け，世界の穀物市場では，ブラジル，アルゼンチン， ロ シア，ウクライナ，モザンビークなどで $1,000 〜 2,000$ ヘ クタール規模での農業開発が進んでいる。その特徵は, 世界的な食糧の商品化であり, 装置化, 機械化, 情報化 農薬肥料を多投する化学化，バイテク化 (生物工学) に よる供給力の飛躍的な拡大である。いわば, 農業の工業 化であり，脱自然化であり，普遍化，単作化（モノカル チャー)でもある。

問題は, 開発のフロンティアが限界地（marginal land）へと広がる中で, 温暖な気候, 水, 肥沃な土壤, 多様な生物といった，これまで希少性と関係のなかった ものが希少性の性格を帯びつつあることだ。食糧も，太 陽の光と土と水があればいくらでも再生産できたが，い まや「有限の資源化」や「自然の劣化」が懸念されるよ うになってきた。

その象徵が地球温暖化に伴う異常気象の常態化である。 気候変動に関する政府間パネル (IPCC:Intergovernmental Panel on Climate Change）は2014年の第 5 次報告書で, 「地球温暖化の進展で穀物生産量が減少し，世界的な食 糧危機を招きかねない」と農業生産への影響を強く警告。 近年の異常気象について, 雨が降り安い地域ではより多 雨となり, 乾燥地域ではより雨が降りにくくなるなど, 気候が「極端化」していると指摘している。特に，IPCC は2019年 8 月 8 日，温室効果ガス排出削減効果が十分に 進まなければ，気温上昇などによる食料生産へ悪影響が 拡大し，2050年に国網価格が最大 $23 \%$ 上昇する恐れがあ り，食料不足や飢餓のリスクが高まるとの「特別報告書」 を発表。これら報告を受けて，各国の地方自治体の中に は, 「気候変動非常事態宣言 (Climate Emergency Declaration=CED）」を議決するところも増えている ${ }^{3}$ 。

\section{7。世界の食品ロス問題}

国連児童基金（UNICEF）によれば，世界の飢餓人口
は増え続けており，2017年には 8 億 2,100 万人に達した。 この一方，FAOによれば，世界の食料生産（2011年） の内, 食品廃棄物・食品口ス (穀物, 酪農品, 水産物, 肉類, 油糧種子, 根菜) は13億トンで, 生産量全体の 3 分の 1 を占めている。

\section{8. 食のグローバル化で「食生活」の危機： 「3つの安定」が脅かされる}

フードシステム (Food System) という言葉は馴染み が薄いが，「食料の供給システム」を指す言葉である。 具体的には, 農水産物の生産段階から, 食品メーカー, 流通業者，外食産業，最終消費に至る食糧のトータルシ ステムの意であり，システムに影響を及ぼす諸制度や行 政措置，技術革新などを含む先進国での概念だ。そもそ も食料不足問題を抱えた発展途上国などにはフードシス テムは馴染まない。この意味で, フードシステムとは, 成熟化した先進国の食料市場に関する捉え方といえよう。 かつて自給自足の時代は, その土地で採れた食料を, そ の地で食べるという意味で，【農＝食】であった。

しかし，経済発展に伴い都市化が進むと，都市と農村 が分離するようになった。さらに食品流通のグローバル 化により，外国産原料の輸入急増や食品産業それ自体の 海外生産シフトが進む一方，国内の農業生産の縮小（食 品産業の国内農業資源からの分離）が進んだ。フードシ ステムの推進役も国内から海外へと移り，これにより フードシステム内部における国内農業と食品産業との関 係がより希薄になる。なお，これらの分析は下渡敏治 (日 本大学教授）の「食品産業のグローバル化の下での国内 農業の課題」(フードシステム研究) に詳しい。

食のグローバル化が進む過程では，日本は安い価格で 良質の食料を，いくらでも海外から調達することができ た。しかし，2000年代に入って，国際食糧市場が一段と 不安定化する中，日本がこれまで享受してきた「価格 (Low Price)」「品＼cjkstart質（Food Safety）」「供＼cjkstart給（Food Security)」の「3つの安定」はもはや保障されなくなっ た。中国や新興国の食料需要拡大で日本企業には「買い 負け」現象がみられるようになる一方，日本のフードシ ステムが, 距離 (生産地から消費地までの距離), 時間 (生 産から消費までの時間)，付加価值（原料から加工食品 までの付加価值）の 3 つの面で食のグローバル化が進ん だためである。私はこれを「くっつく農業」から「離れ る農業」への転換と称している。問題はその結果, 日本 のフードシステムが複雑化しかつブラックボックス化し たことだ。世界的な低価格競争も激化した結果，今世紀 に入ってさまざまな食品産業に不祥事が生じるように なった。アラン・ラペル・シェルは『価格競争は暴走す る』で，「商品が安いのは人間が安いということ。人間

32019 年 9 月29日現在, アルゼンチン, オーストラリア, アメリカ, イギリス, スイス, イタリア, ドイツなど $20 か$ 国の 1,075 自 治体（住民総数約 2 億 6,585 万人）。 
が安いというのは，国家が安いということ」だとして行 き過ざた低価格競争について警鐘を鳴らしている。消費 者には，適正価格を知る力と，その上で国内商品をしっ かりと買い支える覚悟が必要なのである。

\section{9. 日本の食料安全保障は大丈夫か}

食のグローバル化が進む一方で，消費者の間には国内 農業に期待する動きも強まっているようだ。「離れる農 業」から「くっつく農業」への回帰である。しかし, 日 本の農業はこうした消費者の期待に応えることができる であろうか。

こうした中，2018年度の食料自給率は過去最低の $37 \%$ を記録した。農林水産省はコメの消費減少や畜産物の輸 入増加が主要因としている。果たしてそうか。1999年に 制定された「食料・農業・農村基本法」(第 2 条）に㧈 ける食料安全保障は，「国民に良質の食料を安定的に供 給すること」と謳っている。そのための手段として, 生 産力（自給力）をべースに, 備蓄, 輸入（輸入先の多角 化）を適宜組み合わせるとしている。しかし，実態は， 世界の食糧市場は一段と不安定化する中, 備蓄は米を除 いて基本的に流通在庫に止まっている。最大の問題は, 国内農業の生産基盤の弱体化に歯止めがかからないこと にある。

農林水産省では2019年 9 月 6 日, 新たな「食料・農業・ 農村基本計画」の策定に向けた検討を開始した。基本計 画は，今後10年程度先までの施策の方向性を示しつつも， 農政を巡る情勢変化および施策の効果に関する評価を踏 まえ，お抢むね 5 年ごとに見直されることになっている。 基本計画は,「食料・農業・農村基本法」によって政策 の枠組みが定められて抢り, (1)食料の安定供給の確保,

(2)農業の多面的機能の発揮, (3)農業の持続的な発展, (4) 農村の振興の 4 つの政策理念が揭げられている。

農村の振興と農業の持続的な発展を図ることで, 食糧 の安定的な供給が可能になり, 同時に農業の多面的な機 能も発揮されることになるとの考えによる。しかし，現 実には，こうした「予定調和」が達成できるわけではな い。それにもかかわらず, アべノミクスの「攻めの農業」 は, 一部特定の企業的農業を支援することで, 表向きの 農業成功体験を喧伝してきた。この結果, 日本農業の弱 体化が一段と加速することになったといえよう。

\section{0. 弱体化する国内農業の生産基盤と 米関連政策の推移}

日本の農業を考える場合,「まるごと」という概念が 重要だ。思想家の鶴見俊輔によれば,「まるごと (whole)」 と「全体（total）」は異なる。「全体」はあくまでも均質 集合としての意味で, その相互要素間の関倸性は薄い。 これに対し，「まるごと」は, 人間の手, 足, 指, 頭, 目など, 構成要素が相互に結び付いて有機的に働くイ メージである。日本の農村社会では, これまで, 農地, 水,
水源涵養林, 地域住民といった構成要素が,「全体」と してではなく「まるごと」として有機的に働いてきた。 それを維持・保全してきた最大要素が全国, 津々浦々に ある水田農業，すなわち米作りである。

経済学者の宇沢弘文は, 社会的共通資本 (Social Overhead Capital）として道路, 上下水道, 公的な交通 機関, 電力, 通信施設, 司法, 教育, 医療などの文化的 制度や金融・財政制度などを取り上げている。これらに 加え, 水田農業をべースにした農業・農村社会は, 土地 をはじめ大気, 水, 森林, 河川海洋なども社会的共通資 本として捉えるべきであると強調している。しかしなが ら, 水田面積は減少傾向にある。米は消費減退により国 内生産も減少し, 足元では食用米の生産は800万トンを 下回っている。この結果, 社会的共通資本である農業資 源を「まるごと」維持できなくなっている。

こうした状況下, アベノミクスの「攻めの農業」は, 「担 い手」への農地集積を2023年度までに 8 割にするという 目標を揭げている。「担い手」とは, 市町村により認定 された「認定農業者（個人, 法人)」など, 政府が支援 を集中する先としている農業者のことで，いわば日本農 業の将来像を担う農業者という位置付けだ。確かに, 農 地面積に占める「担い手」の利用面積は, 2001年の $27.8 \%$ から2016年には52.3\%と約半分を占めるようになった。 しかし, その後の伸びは鈍化している。全体の農地面積 が減少する中で, 担い手の利用比率が上昇しているのが 実情のようだ。ここ数年農地の集積が足踏み状態にある のは, 対象が平地など条件の良いところから中山間地な ど条件の不利な地域に及んでいるためとみられる。こう した地域では, 離農する農家は増えても, それを引き受 ける担い手農家は少ない。このため自給的農家を含む小 規模農家が依然として多く, 大規模経営体と小規模農家 の二極分化や「土地持ち非農家」も増えている。こうし た状況下で，80\%の農地を担い手に集中していくことが 可能なのか。規模を拡大し大型機械化による労働生産性 の向上を目指す方向での農業構造改善はいまや限界に近 づいたともいえよう。

\section{1. 農産物輸出戦略の成果と課題}

アベノミクスの「攻めの農業」では, 農地規模の拡大 一 6 次産業化一輸出拡大がワンセットになっている。農 業の生産性を高め, 競争力を強化するためには担い手に 農地を集積し, 20ヘクタールを超える大規模農家・経営 体の数を増やす。そうした, 大規模経営体は, 単に米や 果樹, 野菜, 酪農, 肥育牛を生産するだけではなく, 加 工，流通，販売などの 6 次産業化を進め，あわよくば輸 出に打って出るというものだ。こうした構想自体は否定 されるものではない。

農林水産物の輸出の伸びが鈍化している。2019年 1 ～ 9 月の農林水産物 ·食品の輸出額は, 6,645 億円で前年 同期比 $1.6 \%$ 増に止まった。年換算では 9,000 億円に満た 


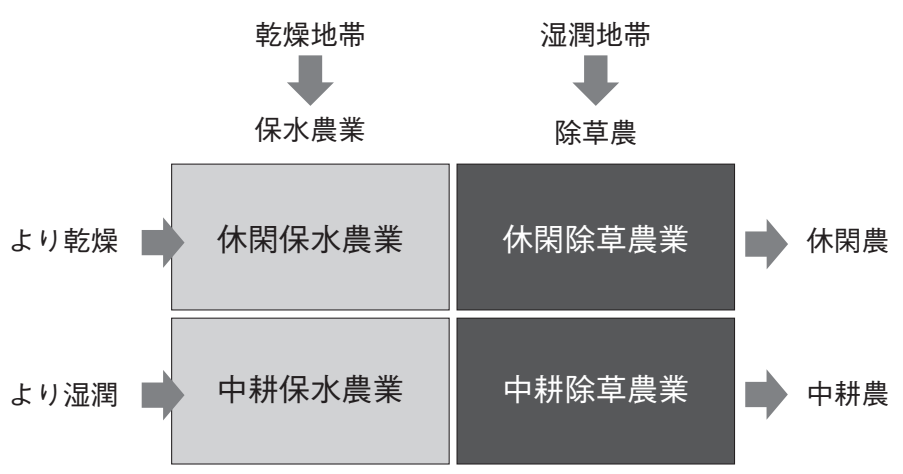

図 3 世界の農業パターン

出所）飯沼二郎：日本農法の提唱（1977）

ず，政府が令和元年の目標とする 1 兆円の達成は難しい 状況た。農産物の輸出は 4,273 億円で同 6 \%増えたものの, 水産物や林産物は減少した。こうした状況にもかかわら ず，安倍政権は「輸出で稼げる日本農業を作る」として， 2030年に農産物輸出（食関連産業の海外売上高） 5 兆円 の目標を掲げている。農林水産政策研究所の推計による と，2030年の世界の飲食料市場規模は1360兆円となり， 2015年の890兆円から1.5倍になると見込まれることから， この一部を取り込もうということらしい。

人口が減少していく国内市場に掠いて, 現在の農地 440万ヘクタールを維持するためには, 確かに国内の農 業資源をフル活用して輸出活路を拓くしかあるまい。政 府はそのための具体策として, 日本の食材の活用や食文 化・食産業の海外展開, 日本の農林水産物の輸出拡大推 進を狙いとした FBI（Made From Japan, By Japan, In Japan）戦略を進めている。2019年 8 月に立ち上げた GFP (ジー・エフ・ピー) は, 輸出を意欲的に取り組も うとする生産者・事業者等のサポートと連携を図るもの だ。しかし, 私には, そ机ら戦略の大半は, 隔靿掻痒の もどかしさを感じる。輸出を拡大しようとしても, 肝心 の日本農業の生産基盤が弱体化しているためである。

日本農業にとってみれば, 農産物の輸出拡大が最終 ゴールではないはずだ。持続的な農産物輸出体制を構築 することで, 日本の農業資源（人，農地，水，水源涵養 林, 地域社会など）をフル活用し, 地域社会の活性化と 持続可能な発展を達成することこそが真に目指すべき姿 である。そのためには, 特定の企業的農家だけでなく, 日本農業の太宗を占める条件不利地域の中小零細農家の 参画が不可欠なのである。

\section{2. まとめ：伝統にもとづく農業改革を}

今後, 日本の農業政策は大規模農業を目指すよりも, 中山間地域の自然に見合った小規模農家による「複合経 営」を支援すべきではあるまいか。条件不利な地域にお いては，いたずらに経営規模を拡大し労働を粗放化する よりも, 経営を内向きにして, 稲作を核に畑作, 果樹, 畜産など複合化することで経営の生産性向上を目指す。
そこに新技術を導入することで地域の農業・農村，ひい ては国土保全, 政府が進める国土強勒化にもつながる。 いわば「伝統にもとづく農業改革」の推進である。

この点, 参考にすべきは飯沼二郎 (京都大学教授当時) の『日本農法の提唱』(富民協会) であろう。飯沼は, 世界の農業パターンを「湿潤地帯の除草農業」と「乾燥 地带の保水農業」に二分する（図 3)。農業は, まず気 候的に最も恵まれていた熱帯地方で鈥農耕として発達し, 次いで，気候的には上り恵まれていない温帯地方に農業 を広めていく過程で, 犂農耕として発達していった。そ して技術が発達し, 資本が蓄積されてくるにしたがって, 人類はしたいに生産の場を乾燥地带から湿潤地帯へと進 めていくと指摘する。乾燥地帯では, 犁は主として地面 からの水分の蒸発を防ぐために土を浅く耕し, 地中の毛 細管現象を切断するために用いる (中耕保水)。これに 対して, 湿潤地帯では錅は主として雑草を除去するため に土を深く耕し，かつそれを反転するのに用いられると 指摘している (中耕除草)。ちなみに, 中耕とは作物と 作物の間の土を耕すことだ。

ヨーロッパやアメリカのような乾燥地帯の農業では, 土地生産性が低いため地力維持のために休閑する必要が ある。こうした休閉農業では農地を広げて機械を導入し 労働粗放的にすればするほど経営は効率化する。そこで は特定の儲かる作物に集中する単作化が必然となる。こ れに対し，日本のような湿潤地帯（中耕除草地域）では, 土地面積を拡大するよりも労働の投下を増大する方が経 済的に合理的であるとした。すなわち，休閑農業に扔け る発展方向が労働粗放化の方向を目指すのに対して, 中 耕農業に扔ける発展方向は労働集約化を目指すと喝破し た。ただし，中耕農業は，労働集約的にすればするほど， 農作業の繁閑の差が大きくなるので，それを平準化する ために複合経営のようなかたちで経営を複雑化させざる を得ないとした。

このようにみると, 戦後の特に1961年の農業基本法の 農業近代化は, 乾燥地帯のアメリカやヨーロッパ農業を 目指すものであり，湿潤地帯という日本の農業にはそぐ わないものであるとして, 農業基本法の農業近代化は真 
の近代化ではないと主張し続けた。当然彼の主張は農政 に受け入れられるものではなかった。考えてみれば，農 業近代化を推進するエンジンとなった農業構造改善事業 というものは, 日本の風土・自然を取りあえずさて置い て, 規模拡大 $\Rightarrow$ 大型農業機械の導入 $\Rightarrow$ 余㮃労働力の排出 といった方向で進められてきたものであり，現在のアべ ノミクス「攻めの農業」もその方向に拍車をかけるもの である。しかし，自然を無視した近代化がいたる所で限 界を見せていることは確かである。今後は，それぞれの 地方の「自然の額縁」の中で, 以下に農業を合理化·近 代化するかという逆転の発想が必要ではないか。また,

農業は農村という場で営まれるものであり, そこにある 農村地域社会と不可分であることを再認識すべきであろ う。

\section{文献}

- 農林水産省：主要統計, https://www.maff.go.jp/j/tokei/ kouhyou/kensaku/bunya2.htm

. 農林水産省 : 食料 ·農業 - 農村白書 令和元年版 (2019)

・宮本常一：食生活雑考, 未来社 (1977)

・ 下渡敏治：食品産業のグローバリズムの下での国内農業の 課題, フードシステム研究 9 (2)，17-29（2003）

- USDA : World Agricultural Supply and Demand Estimates

- Edward O. Wilson : THE DIVERSITY OF LIFE, Harvard University Press (1992)

· 飯沼二郎：日本農法の提唱, 富民協会 (1977) 